\title{
Dźwięki reaktywne, dźwięki antycypujące. Z zagadnień funkcjonowania ścieżki dźwiękowej $w$ grach wideo
}

\author{
JOANNA PIGULAK \\ Instytut Filmu, Mediów i Sztuk Audiowizualnych \\ Uniwersytet im. Adama Mickiewicza w Poznaniu
}

\begin{abstract}
Pigulak Joanna, Dźwięki reaktywne, dźwięki antycypujące. Z zagadnień funkcjonowania ścieżki dźwiękowej w grach wideo [Features of the reactive and anticipating sounds in video games]. "Images" vol. XXVIII, no. 37. Poznań 2020. Adam Mickiewicz University Press. Pp. 317-327. ISSN 1731-450X. DOI 10.14746/i.2020.37.18]

The paper aims to outline features of video games' sounds. In order to do that, the author presents the main thesis of ludomusicology and a theory of film music. The first part of the paper deals with a brief introduction concerning the characteristic of two important aspects of video games' sounds: reactive and anticipating sounds. In the second part of the paper, the author explores the issue of facultative dialogues and adaptive sounds, as well as diegetic and non-diegetic sources of sound. The author examines the hypothesis that using sounds in video games determines gameplay and impacts players immersion.
\end{abstract}

KEYWORDS: ludomusicology, interactive music, reactive sounds, adaptive sounds, anticipating sounds

\section{Wprowadzenie}

Za moment przełomowy dla naukowej refleksji nad audiosferą gier wideo[1] można uznać pierwszą dekadę XXI wieku, gdyż wtedy przyjęła ona zinstytucjonalizowaną formę. Chociaż badania dotyczące funkcjonowania ścieżki dźwiękowej w mediach interaktywnych prowadzono już w latach dziewięćdziesiątych ubiegłego stulecia, to dopiero około roku 2007 wykształciła się odrębna dyscyplina akademicka określona mianem ludomuzykologii (ludomusicology)[2], łącząca badania nad grami cyfrowymi z teoriami muzyki[3]. Jej dynamiczny rozwój, zwłaszcza w Stanach Zjednoczonych, zaowocował powstaniem licznych prac podejmujących temat wykorzystania ścieżki dźwiękowej w grach. Należą do nich zarówno przekrojowe monografie funkcjonalizujące zastosowanie warstwy audialnej w mediach interaktywnych[4], praktyczne podręczniki dla kompozytorów[5], jak i prace teoretyczne pisane z perspektywy muzykologów, ważne ze względu na to, że autorzy podejmują próby terminologicznego uporządkowania zagadnienia audiosfery gier[6].

Przywołane pozycje cechuje ujęcie intermedialne - ich autorzy odwołują się do metod wy-
[1] Terminów „warstwa audialna”, „ścieżka dźwiękowa” oraz „audiosfera” używam zamiennie, opisując wszystkie elementy składające się na dźwięk w grach wideo (należą do nich muzyka, odgłosy, szmery, cisza oraz dialogi, a także monologi i wypowiedzi z offu, a więc każdy sposób artykulacji słów przez aktorów). Określenia te są synonimicznie wykorzystywane w pracach dotyczących dźwięku w filmie (zob. między innymi P. Pomostowski, Reżyser na ścieżce dźwiękowej. Funkcje muzyki w twórczości filmowej Romana Polańskiego, Poznań 2018; J. Pająk, Dźwięk w filmie. Między sztuką a rzemiosłem, Warszawa 2018).

[2] Neologizm „ludomuzykologia” został wprowadzony do dyskursu akademickiego przez groznawcę i muzykologa Guillaume’a Laroche'a w roku 2007 (R. Moseley, Playing games with music (and vice versa): ludomusicological perspectives on guitar heroand rock band, [w:] Taking It to the Bridge: Music as performance, red. N. Cook, R. Pettengill, Michigan 2013, s. 283).

[3] Z. Whalen, Play along - an approach to videogame music, „Game Studies: The International Journal of Computer Game Research" 2004, nr 4(1), <http://www.gamestudies.org/o401/whalen/>, dostęp: 15.12.2019.

[4] Zob. między innymi K. Collins, Playing with Sound: A theory of interacting with sound and music in video games, Cambridge 2013; T. Summers, Understanding Video Game Music, Cambridge 2016. 
[5] Zob. między innymi W. Phillips, A Composer's Guide to Game Music, Massachusetts 2014; M. Sweet, Writing Interactive Music for Video Games: A composer's guide, New Jersey 2015. [6] Warto w tym kontekście przywołać pracę T. Richarda oraz D. Summersa Video Game Music: History, form and genre (Bristol 2012), której autorzy forsują termin „gatunek interaktywny” (interactive genre) w odniesieniu do gier, w których użytkownik decyduje o tym, jakie dźwięki zaistnieją w rozgrywce (na przykład Guitar Hero, Harmonix Music System, 2005-2015). Interesującą, muzykologiczną perspektywę prezentuje również Alyssa Aska w monografii Introduction to the Study of Video Game Music (ebook, Lulu.com 2017), która nie tylko porządkuję terminologię dotyczącą dźwięków w grach wideo, ale również skupia się na wpływie technologii na konstrukcję warstwy audialnej, a także na jej recepcję.

[7] Zob. oprócz wspomnianych prac również K. Collins, Game Sound: An introduction to the history, theory, and practice of video game music and sound design, Cambridge 2008; N. Cook, R. Pettengill (red.), Taking It to the Bridge: Music as Performance, Michigan 2013.

[8] Mowa tutaj zwłaszcza o kompozytorach uznanych w branży i nagradzanych na festiwalach filmowych, którzy zdecydowali się stworzyć muzykę do gier wideo. Należą do nich między innymi: wielokrotnie nominowany do Oscara, Złotych Globów oraz BAFT Hans Zimmer, który skomponował muzykę do Call of Duty 4: Modern Warfare (Infinity Ward, 2007); dwukrotny zdobywca Oscara Gustavo Santaolalla - kompozytor muzyki do gry The Last of Us (Naughty Dog, 2013), czy też Bear McCreary - autor ścieżki dźwiękowej do God of War znany z kompozycji muzycznych do takich seriali telewizyjnych jak Constantine (Daniel Cerone, David S. Goyer, 2014) i Piraci (Jonathan E. Steinberg, Robert Levine, 2014-1017). Są to tylko wybrane przykłady - tendencja do komponowania muzyki do gier wideo przez kompozytorów filmowych jest współcześnie coraz wyraźniejsza.

[9] Gameplay jest zbiorem wszystkich zasad i mechanizmów umożliwiających użytkownikowi interakcję z oprogramowaniem, a w konsekwencji - nawigowanie w rzeczywistości wirtualnej (N. Iuppa, T. Borst, Story and Simulations for Serious Games: Tales from the trenches, Burlington, Oxford 2007, s. 17).

[10] K. Collins, Playing with Sound..., s. 32-43. pracowanych na gruncie nauk muzykologicznych, medioznawczych oraz filmoznawczych. Interesujące okazują się zwłaszcza liczne odniesienia do teorii filmu jako podstawy dociekań naukowych[7], wskazujące, że refleksja nad warstwą audialną gier kształtuje się w nawiązaniu do tradycyjnych mediów audiowizualnych. Takie podejście badawcze wynika z co najmniej dwóch powodów, na które należy w tym miejscu zwrócić szczególną uwagę. Po pierwsze, filmoznawcy wykształcili funkcjonalną bazę terminologiczną dotyczącą dźwięku w filmie. Niektóre pojęcia, jak na przykład muzyka diegetyczna i niediegetyczna, są szczególnie funkcjonalne w kontekście analizy audiosfery tekstów interaktywnych. Po drugie, odwołania do badań z zakresu dźwięku w kinematografii związane są również z praktycznymi aspektami wykorzystania ścieżki audialnej we współczesnych grach wideo - coraz częściej zdarza się, że soundtracki do nich tworzą kompozytorzy filmowi[8]. W niniejszym artykule, mając na uwadze intermedialny charakter omawianego zagadnienia, odwołuję się zarówno do prac ludomuzykologicznych, jak i filmoznawczych. Prezentuję przy tym komparatystyczną metodę badania audiosfery gier, wskazując na podobieństwa i różnice w jej funkcjonowaniu w stosunku do filmu.

Głównym, podejmowanym przeze mnie tematem są sposoby, w jakie designerzy, za pośrednictwem warstwy audialnej, kształtują sposoby interakcji gracza $\mathrm{z}$ wirtualnym środowiskiem. W rozważaniach nad ścieżką dźwiękową gier cyfrowych interesuje mnie zwłaszcza to, jak jej użycie wpływa na gameplay [9]. Z tego powodu skupiam się na tych aspektach audiosfery, które istotnie oddziałują na nawigowanie użytkownika w świecie diegetycznym (a w konsekwencji również - na rozwój narracji). Należą do nich przede wszystkim dźwięki, które, odwołując się do prac wybitnej ludomuzykolożki Karen Collins, nazywam reaktywnymi i antycypującymi[10].

Audiosfera gier wideo może być częściowo kreowana przez użytkownika. Dzieje się tak, gdy interakcja z oprogramowaniem skutku- 
je powstaniem określonych dźwięków. Kiedy w God of War (SIE Santa Monica Studio, 2018) tytułowy bóg wojny Kratos rzuca swoim toporem, ma również możliwość przyzwania go z powrotem (użytkownik czyni to, wybierając ikonę trójkąta na kontrolerze PlayStation). Powracająca broń wydaje charakterystyczny odgłos, przecinając ze świstem powietrze. Słysząc ten dźwięk, gracz nie tylko wie, że użyta komenda zadziałała, ale również może zorientować się, z której strony nadleci topór. Co istotne jednak w kontekście niniejszych rozważań, pojawienie się dźwięku jest w powyższej sytuacji konsekwencją interakcji użytkownika z systemem, a zatem stanowi rezultat jego aktywności. Ten aspekt audiosfery określam mianem reaktywnego - dźwięki reaktywne pojawiają się w grze bezpośrednio $\mathrm{w}$ następstwie interakcji użytkownika z systemem[11].

Niektóre aspekty warstwy dźwiękowej w grach wideo generowane są przez oprogramowanie automatycznie, a więc niezależnie od gracza. Rytm i tempo muzyki w God of War zmienia się, kiedy protagonista zostaje zaatakowany przez wrogów. W ścieżce audialnej wykorzystane zostają również dodatkowe instrumenty muzyczne, takie jak werble. Nawet jeśli wrogowie znajdują się w przestrzeni pozakadrowej, a więc gracz w danym momencie nie może ich zobaczyć, to przetworzenia w obrębie audiosfery wskazują, że za chwilę odbędzie się walka. Użytkownik ma czas, aby przygotować się do ataku i wyjąć broń oraz tarczę. Gracz, za pośrednictwem awatara, podejmuje zatem adekwatne czynności, słysząc opisywane dźwięki. Nazywam je antycypującymi, gdyż zapowiadają określone zdarzenia narracyjne (oraz nadają im odpowiedni kontekst interpretacyjny), a tym samym budują oczekiwania względem tego, co wkrótce wydarzy się w świecie diegetycznym[12]. Celem dźwięków antycypujących jest prowokowanie gracza do aktywnego reagowania w scenie - bezpośrednio wpływają więc na gameplay.

W niniejszym artykule prezentuję różnorodne funkcje oraz przykłady użycia dźwięków reaktywnych i antycypujących w grach wideo, aby wykazać, w jaki sposób determinują one rozgrywkę oraz ustalają, a także utrwalają zasady, w zgodzie z którymi użytkownik nawiguje w cyfrowym środowisku. Refleksję nad dźwiękami reaktywnymi i antycypującymi umieszczam w szerszym kontekście, skupiając się na trzech właściwościach digitalnej audiosfery: fakultatywnej dialogiczności, adaptatywnym charakterze dźwięków i diegetycznych i niediegetycznych źródłach dźwięku[13].

\section{Fakultatywna dialogiczność}

Badacze, rozważając rolę dialogów w filmie dźwiękowym, wskazują, że są one podstawowym elementem kinematograficznej audiosfery[14]. Takie rozpoznanie pojawia się między innymi w przełomowej książce Audio-wizja. Dźwięk i obraz w kinie autorstwa Michela Chiona, w której francuski filmoznawca i kompozytor, analizując zależności między warstwą audialną oraz wizualną filmu, dowodzi, że:

Dźwięk w kinie ma prymat głosu, [...] niemal we wszystkich przypadkach głos zajmuje miejsce uprzywilejowane, jest on podkreślany i oddzielany od innych dźwięków. Podczas kręcenia filmu, nagrywając dźwięk, zapisuje się przede wszystkim głos, przecież najczęściej jest to po prostu nagrywanie głosu, wreszcie podczas opracowania dźwiękowego to właśnie głos jest specjalnie oddzielany, zupełnie jak solowy instrument, przy którym inne

[11] A. Aska, op.cit., s. 72.

[12] D. Bordwell, K. Thompson, Film Art. Sztuka filmowa, przeł. B. Rosińska, Warszawa 2014, s. 297.

[13] Powyższy zbiór nie wyczerpuje wszystkich właściwości audiosfery gier wideo. Nie analizuję między innymi takich parametrów dźwięku, jak barwa, natężenie i wysokość, ani sposobów miksowania dźwięków i łączenia ich z obrazem. Zawężenie materiału badawczego do trzech wybranych cech digitalnej warstwy audialnej wynika $\mathrm{z}$ faktu, że celem niniejszego artykułu nie jest całościowe wyjaśnienie omawianej problematyki, ale wskazanie na reaktywne i antycypujące aspekty audiosfery, które istotnie stymulują interakcje gracza $\mathrm{z}$ wirtualną rzeczywistością.

[14] Zob. między innymi J. Pająk, op.cit., s. 35;

D. Bordwell, K. Thompson, op.cit., s. $3 \mathrm{O} 2$. 
dźwięki, melodie i szumy stanowią jedynie akompaniament[15].

Chion zwraca uwagę, że głos w kinie stanowi podstawowy element audialnej ekspresji, gdyż towarzyszy człowiekowi również w codziennym życiu, a za pośrednictwem dialogów (oraz monologów i innych form artykulacji słów przez aktorów) reżyserzy rozwijają narrację, porządkują ją oraz hierarchizują zdarzenia rozgrywające się w świecie diegetycznym. Podkreślana przez autora rola dialogu $\mathrm{w}$ filmie jest znamienna, biorąc pod uwagę sposób, w jaki funkcjonuje on w pokrewnym medium audiowizualnym - grach wideo. Choć współczesne gry są w większości w pełni zdubbingowane, to zdarza się, że twórcy zupełnie rezygnują z wykorzystania dialogów[16]. Innymi słowy, dialogi w grach cyfrowych funkcjonują jako fakultatywny element audiosfery.

Nieobecność dialogiczności cechuje zwłaszcza gry logiczne, zręcznościowe oraz platformowe, a zatem takie, w których istotniejszy niż opowiadanie historii staje się gameplay. Designerzy tego rodzaju gier wykorzystują rozbu-

[15] M. Chion, Audio-wizja. Dźwięk i obraz w kinie, przeł. K. Szydłowski, Warszawa, Kraków 2012, s. 11. Prace Michaela Chiona cytuje Karen Collins, między innymi w książce Playing with Sound: A Theory of Interacting with Sound and Music in Video Games. Ludomuzykolodzy w swoich rozważaniach często odwołują się do badań filmoznawczych.

[16] Oczywiście, po przełomie dźwiękowym w roku 1927 również powstawały (i wciąż powstają) filmy pozbawione dialogów, jednak najczęściej są one zaliczane do kina eksperymentalnego (na przykład surrealistyczne etiudy Jana Švankmajera, jak chociażby Jedzenie z 1992) bądź też stanowią hołd dla kina niemego i odwołują się do jego poetyki (na przykład Artysta, Michel Hazanavicius, 2011). [17] M. Glasser, Dialog in film and fiction, [w]: Explorations in National Cinemas. The 1977 Film Studies Annual: Part One, red. B. Lawtion, J. Staiger, New York 1977, s. 2.

[18] N. Lerner, Mario's dynamic leaps: Musical innovations (and the specter of early cinema) in Donkey Kong and Super Mario Bros., [w:] Music in Video Games: Studying Play, red. K.J. Donelly, W. Gibbson, N. Lerner, New York 2014, s. 7 [tłum. własne]. dowane mechaniki rozgrywki umożliwiające graczowi różnorodne interakcje $\mathrm{z}$ oprogramowaniem. Ograniczona warstwa fabularna rekompensowana jest możliwością rekonfiguracji poszczególnych elementów rzeczywistości wirtualnej, ale skutkuje minimalizacją bądź zupełną eliminacją, ścieżki dialogowej. Takie rozwiązanie charakteryzuje między innymi gry przeznaczone na automaty arkadowe oraz konsole ośmiobitowe (zob. Donkey Kong, Nintendo, 1981; Super Mario Bros., Nintendo, 1985). Nieobecność dialogiczności nie jest jednak wyłącznie cechą produkcji elektronicznych powstających u zarania rozwoju przemysłu gier wideo. Również współcześnie odnaleźć można liczne realizacje, w których twórcy rezygnują z dubbingu - wystarczy wspomnieć debiutancką grę studia Playdead, czyli Limbo (2010) albo digitalną baśń, łączącą w sobie cechy gry platformowej oraz przygodowej - Brothers: A Tale of Two Sons (Starbreeze Studios, 2013). Powyższe gry są udźwiękowione, tj. ich warstwa audialna składa się z muzyki i odgłosów, jednak designerzy zrezygnowali z użycia ścieżek dialogowych.

Jak zostało wspomniane, za pośrednictwem dialogów twórcy filmowi prezentują różnorodne narracje, rozwijają i kształtują ekranowe opowieści, ale również charakteryzują postacie biorące udział w zdarzeniach. Dialogi uzupełniają znaki wizualne - stanowią ważne źródło wiedzy odbiorcy o bohaterach i ich sytuacji życiowej. Aktorzy wyrażają całe spektrum emocji za pomocą tonu głosu, rytmu dialogów oraz natężenia ich dźwięku[17]. Informacyjno-afektywną funkcję dialogu przejmują w niedialogicznych grach wideo inne dźwięki audiosfery. Neil Lerner, analizując ścieżkę audialną Donkey Konga, wskazuje, że „W grze wykorzystany został wiodący motyw dźwiękowy w celu zunifikowania różnorodnych poziomów gry i akcji. Momentami przerywa go chromatyczna muzyka towarzysząca śmierci bohatera, która stanowi kontrast dla dźwięków (takich jak odgłos skakania i uderzania młotem), będących klamrą spajającą każdy poziom"[18].

Opisana przez Lernera chromatyczna muzyka w Donkey Kongu informuje o śmierci 
protagonisty, a zatem o porażce użytkownika, który w tej sytuacji musi powtórzyć dany etap rozgrywki. Za jej pośrednictwem twórcy nie tylko jednak kształtują istotne fabularnie znaczenia, odnoszące się do funkcjonującego $\mathrm{w}$ świecie przedstawionym protagonisty, ale również projektują przekaz niediegetyczny, kierowany bezpośrednio do gracza. Ponura tonacja ścieżki dźwiękowej zastępuje werbalny (lub graficzny) komunikat wskazujący na brak postępu w grze. Aby jednak konkretny dźwięk rzeczywiście mógł być kojarzony przez gracza $\mathrm{z}$ określonym zdarzeniem narracyjnym (a więc, aby rzeczywiście przejmował informacyjno-afektywną funkcję dialogu), musi mieć charakter powtarzalny. Repetycja tych samych dźwięków w określonej sytuacji fabularnej (na przykład śmierci postaci) umożliwia użytkownikowi skojarzenie ich z tą sytuacją.

We wspomnianej grze Limbo, w której główny bohater - kilkunastoletni chłopiec - przemierza tytułową otchłań, celem użytkownika jest ominięcie przeszkód znajdujących się na drodze awatara. Niewypełnienie tego zadania skutkuje śmiercią postaci i koniecznością powtórzenia danego etapu rozgrywki. Porażka protagonisty jest na poziomie audialnym reprezentowana przez całkowite wyciszenie audiosfery - w momencie jego śmierci wszystkie obecne w grze dźwięki zastępuje cisza[19]. Limbo jest interesującym przykładem, że funkcje dialogów (tak istotnych dla poetyki filmu) mogą być w grach wideo zastępowane nie tylko przez niewerbalne elementy ścieżki dźwiękowej, ale i, na skutek jej całkowitej redukcji, wyciszeniem audiosfery.

Warto podkreślić, iż w obydwu analizowanych przypadkach pojawienie się określonych dźwięków jest efektem działań gracza - wynikiem jego interakcji z oprogramowaniem. Oznacza to, że zarówno chromatyczna muzyka w Donkey Kong, jak i cisza w Limbo stanowią przykład dźwięków reaktywnych. W obu grach istnieje możliwość, że użytkownik ani razu nie doprowadzi do śmierci postaci - w takiej, hipotetycznej, ale dopuszczalnej przez system sytuacji ścieżka dźwiękowa będzie zredukowana o analizowane aspekty audiosfery. W przeci- wieństwie do filmu, gdzie dźwięk w swoich najróżniejszych postaciach, tj. dialogów, muzyki, odgłosów, szmerów, szumów oraz ciszy pojawia się w określonych przez reżysera momentach, w grach wideo jego obecność jest determinowana przez aktywność użytkownika. Właściwe dźwiękom reaktywnym sprzężenie warstwy audialnej z działaniami, które podejmuje gracz, nawigując w wirtualnej rzeczywistości, ma określone konsekwencje dla ukształtowania audiosfery. Staje się ona, podobnie jak inne aspekty tekstu interaktywnego, otwarta na rekonfigurację[20]. Każda indywidualna rozgrywka może i będzie - różnić się pod względem konstrukcji warstwy audialnej. Awatar prowadzony przez gracza, który nie jest zaznajomiony z gameplayem czy też niedoświadczony w grach platformowych, najprawdopodobniej zginie wielokrotnie w czasie jednego poziomu gry Donkey Kong, podczas gdy postać gracza doświadczonego - rzadziej bądź ani razu. Obie te sytuacje doprowadzą do różnorodnego brzmienia gry. Istotną właściwością dźwięków reaktywnych jest zatem wariacyjność: ich częstotliwość, zakres i natężenie zmieniają się w zależności od działań podjętych przez użytkownika.

[19] Wykorzystanie ciszy w Limbo pełni, oczywiście, funkcje symboliczne i wpływa na zakres możliwych interpretacji narracji. W odwołaniu do tytułu gry denotuje odniesienia religijne w chrześcijaństwie cisza jest sposobem na uczczenie pamięci zmarłych, ale również momentem refleksji oraz zadumy. W grze Limbo śmierć nie jest ani widowiskowa, ani naturalistyczna, tylko odrealniona i estetyzowana. Użycie ciszy w scenach śmierci podkreśla zatem umowność świata diegetycznego.

[20] Lev Manovich wskazuje, że otwartość na rekonfigurację, a więc na wariacyjność, jest dystynktywną cechą nowych mediów (autor nie używa sformułowania media interaktywne, zastępując je pojęciem nowe media). Badacz tłumaczy, że „obiekt nowych mediów nie jest czymś ustalonym raz na zawsze, ale raczej czymś, co istnieje $\mathrm{w}$ wielu odmiennych od siebie wersjach, których liczba może być teoretycznie nieskonczona". L. Manovich, Język nowych mediów, przeł. P. Cypryański, Warszawa 2006, s. 102. 


\section{Adaptatywny charakter dźwięków}

Cechę swoistą warstwy audialnej gry Limbo stanowią dźwięki wydawane przez pułapki znajdujące się na drodze bohatera. Dla przykładu: oponom toczącym się ze wzgórza towarzyszy jednostajny odgłos tarcia ciężkiego przedmiotu o równą powierzchnię ziemi. Jest on zsynchronizowany z obrazem, a więc symultaniczny do pojawienia się opon w kadrze. System gry uruchamia ten dźwięk w określonym miejscu i na konkretnym etapie rozgrywki, tj. wtedy, kiedy użytkownik dostrzeże, a następnie wejdzie $\mathrm{w}$ interakcję z przeszkodą. Opisywany element audiosfery pełni funkcję ilustrującą oraz stymuluje doświadczanie zdarzeń prezentowanych w przestrzeni kadrowej (jednostajny odgłos tarcia zwiastuje nadchodzące niebezpieczeństwo) - ponieważ jednak 1) pojawia się w zdefiniowanym przez designerów momencie gry, 2) uzupełnia warstwę obrazową i jest jej integralną częścią, dźwięk ten ma charakter adaptatywny. Jak wskazuje Collins, adaptatywna ścieżka dźwiękowa „stanowi reakcję na przebieg gry, co oznacza, że jest z góry zaprogramowana i skonfigurowana z parametrami rozgrywki (między innymi czasowymi). Nie jest natomiast odpowiedzią na bezpośrednie działanie gracza" [21].

Dźwięki o charakterze adaptatywnym są więc, w ujęciu badaczki, ściśle związane $\mathrm{z}$ aspektami temporalnymi gry wideo, z jej własną, wewnętrzną czasowością. Autorka przywołuje przykład Super Mario Bros., aby zilustrować relację między czasem a audiosferą. Celem użytkownika analizowanej gry staje się ukończenie danego poziomu w określonym czasie - o jego upływie informuje niediegetycz-

[21] K. Collins, Game Sound..., s. 8.

[22] Należy przy tym podkreślić, że nie każdy dźwięk adaptatywny jest dźwiękiem antycypującym (i odwrotnie). Opisywane w dalszej części artykułu dźwięki niediegetyczne w Red Dead Redemption II, które pojawiają się zawsze w określonym momencie gry, kiedy użytkownik rozpocznie eksplorację nowego obszaru, nie zapowiadają zdarzeń narracyjnych ani potencjalnych interakcji - wpływają za to na atmosferę sceny oraz charakteryzują odkrywaną lokację. ny zegar w prawym górnym rogu ekranu. Kiedy graczowi pozostaje do zakończenia rozgrywki kilkadziesiąt sekund, przyspiesza kilkukrotnie tempo muzyki, dynamizując gameplay. Opisany przeze mnie przykład zaczerpnięty z gry Limbo odnosi się jednak nie do czasowych, ale do wizualnych parametrów gameplaya. Proponuję, aby w tym kontekście adaptatywne aspekty ścieżki dźwiękowej potraktować jako elementy synchronizujące dźwięk i obraz w celu osiągnięcia określonego efektu dramaturgicznego, na przykład suspensu, jak ma to miejsce w przypadku Limbo. Designerzy wiążą na poziomie znaczeniowym porządek wizualny oraz audialny po to, aby informować użytkownika o zbliżającym się niebezpieczeństwie i konieczności konfrontacji z nim - w ten sposób zwiększają napięcie dramaturgiczne i ekspresywność emocjonalną sceny.

Dźwięki adaptatywne cechuje zatem to, że system gry uruchamia je zawsze, w każdej indywidualnej rozgrywce, w określonym momencie wyznaczanym przez wizualne i/lub czasowe parametry gameplaya. Adaptatywne aspekty audiosfery, choć pozostają poza kontrolą użytkownika, mogą jednak realnie wpływać na sposób nawigowania oraz interakcje $\mathrm{z}$ wirtualną przestrzenią. Dzieje się tak wtedy, kiedy pełnią one funkcję antycypującą[22].

W grze God of War podczas podróży przez krainy składające się na świat nordyckiej mitologii protagonista spotyka krasnoludzkie rodzeństwo - kowali Broka i Sindriego. Nastawieni przyjaźnie wobec Kratosa bohaterowie wspomagają awatara gracza, ulepszając jego zbroje, bronie oraz sprzedając surowce niezbędne mu podczas eksploracji świata. Sklepy braci rozlokowane są w różnych rejonach rozległych przestrzeni Midgardu, Alfheimu, Muspelheimu oraz Niflheimu, a użytkownik odkrywa je $\mathrm{w}$ trakcie rozgrywki. Pojawieniu się sklepu w okolicy zawsze towarzyszy ten sam, charakterystyczny dźwięk: donośny odgłos młota uderzającego o metal. Powyższy element audiosfery God of War ma charakter adaptatywny, gdyż generowany jest przez silnik gry wyłącznie wtedy, kiedy gracz znajdzie się w pobliżu warsztatów 
Broka lub Sindriego. Jest to typowa dla gier wideo, umożliwiających nielinearne nawigowanie użytkownika w digitalnym środowisku, wskazówka dźwiękowa, która pozwala określić położenie obiektów w przestrzeni i ich odległość od awatara. Nie oznacza to jednak, że użytkownik musi skierować digitalny obiektyw na sklep, by usłyszeć odgłos. Dźwięk młota aktywowany jest przez oprogramowanie również wtedy, gdy miejsce pracy krasnoludów pozostaje w przestrzeni pozakadrowej. Gracz, rozpoznając ten element audiosfery, może zboczyć z obranej ścieżki i skierować się w stronę, z której on dochodzi, aby zaopatrzyć się w warsztacie. W tym sensie adaptatywna ścieżka dźwiękowa antycypuje to, co znajdzie się w przestrzeni kadrowej. Pojawienie się odgłosu motywuje użytkownika do zmiany destynacji, a więc realnie wpływa na jego działania.

Wykorzystanie antycypujących dźwięków adaptatywnych pełni jeszcze jedną istotną funkcję - kształtuje oczekiwania gracza odnoszące się do tego, co pojawi się w sferze wizualnej, a zatem pozwala na wyobrażenie sobie wyglądu przestrzeni pozakadrowej. Gdy użytkownik słyszy dźwięk powtarzający się wielokrotnie w tej samej sytuacji, zakłada, że w pobliżu awatara znajdują się zsynchronizowane $\mathrm{z}$ nim obiekty (na przykład warsztat krasnoludów w God of War) i na tej podstawie decyduje, czy powinien się w ich stronę udać. Jeśli, mimo charakterystycznego odgłosu, na miejscu nie zastałby ani Broka, ani Sindriego, to zaburzona zostałaby koherencja dźwięku i obrazu.

Jesper Kaae twierdzi, że adaptatywna ścieżka audialna charakteryzuje się natychmiastowością, tj. silnik muzyczny bez opóźnień reaguje na to, co wytworzy silnik graficzny[23]. Innymi słowy, dźwięki adaptatywne w ujęciu Kaae'ego uruchamiają się wtedy, gdy w kadrze pojawią się zsynchronizowane $\mathrm{z}$ nimi elementy wizualne. Proponuję jednak, mając na uwadze powyższe rozpoznania, aby rozszerzyć to stwierdzenie w następujący sposób: dźwięki adaptatywne włączają się wtedy, gdy powiązane $\mathrm{z}$ nimi obiekty graficzne znajdują się $\mathrm{w}$ kadrze lub gdy wykorzystywane są w funkcji antycy- pującej i zapowiadają to, co dopiero pojawi się $\mathrm{w}$ kadrze, ale na razie pozostaje $\mathrm{w}$ przestrzeni pozakadrowej. W tej drugiej sytuacji użycie adaptatywnej audiosfery stymuluje interakcje gracza z wirtualną rzeczywistością. Odwołanie do zmysłu słuchu pomaga w skupieniu uwagi użytkownika na określonym aspekcie świata przedstawionego, który wydaje się istotniejszy (narracyjnie, poznawczo, epistemiczne) od tych nieposiadających w danym momencie swojej reprezentacji dźwiękowej i służy nakłonieniu go do interakcji z tym elementem.

\section{Diegetyczne i niediegetyczne źródła dźwięku}

Opisane antycypujące dźwięki adaptatywne są diegetyczne, gdyż ich źródło znajduje się w świecie przedstawionym - zarówno odgłos staczającej się ze wzgórza opony, jak i uderzeń młota pochodzi z rzeczywistości cyfrowej. Przykład przywołany we wprowadzeniu niniejszego artykułu, który dotyczy zmieniającej się muzyki w czasie scen walki w God of War, świadczy o tym, iż dźwięki antycypujące mogą być również niediegetyczne. Muzyka generowana przez oprogramowanie podczas ataku wroga nie ma swojej przyczyny w świecie gry - na polu walki nie znajduje się bowiem orkiestra, która wybijałaby rytm na werblach. Dźwięki reaktywne również mogą być diegetyczne (świst przyzywanego topora) bądź niediegetyczne (muzyka ilustrująca śmierć bohatera w Donkey Kong).

Określenia „diegetyczny” i „niediegetyczny”, odnoszące się do przynależności bądź nieprzynależności elementów audiosfery do świata przedstawionego, wywodzą się z badań filmoznawczych. Spopularyzowali je David Bordwell oraz Kristin Thompson, którzy konsekwentnie wykorzystują te terminy nie tylko w książce Film art. Sztuka filmowa (2014), ale również na prowadzonym od 2006 roku popularnym blogu

[23] J. Kaae, Theoretical approaches to composing dynamic music for video games, [w:] From Pac-Man to Pop Music: Interactive Audio in Games and New Media, red. K. Collins, Surrey 2008, s. 84 . 


\section{4}

VARIA

internetowym (www.davidbordwell.net). Warto podkreślić, iż jest to tylko jedna z propozycji terminologicznych, rozróżniająca elementy ścieżki dźwiękowej ze względu na ich źródło. W literaturze naukowej funkcjonuje znacznie więcej pojęć określających to, co nazywam dźwiękami diegetycznymi i niediegetycznymi. Wspomniany Michael Chion proponuje użycie sformułowań „muzyka ekranu” (screen music) w odniesieniu do tych aspektów warstwy audialnej, które przynależą do filmowej diegezy, oraz „muzyka z fosy” (pit music) - terminu wywodzącego się z opery i charakteryzującego dźwięki pozadiegetyczne[24]. W pracach filmoznawczych można odnaleźć jeszcze inną terminologię, określającą kolejno dźwięki diegetyczne i niediegetyczne: muzyka źródłowa (source music) i muzyka $\mathrm{z}$ tła (background music)[25]; source music oraz score music[26], czy też muzyka wewnętrzna i zewnętrzna[27].

Nie jest moim celem rozstrzyganie, która z przytoczonych propozycji terminologicznych

[24] M. Chion, op.cit., 1982; idem, Le son au cinéma, Paris 1985, s. 122-123. Podaję za: P. Pomostowski, op.cit., s. 28.

[25] M. Slowik, After the Silents: Hollywood film music in the early sound era, 1926-1934, New York 2014, s. 55.

[26] Terminów source music oraz score music używa, między innymi, Krzysztof Kozłowski, który zaadaptował na grunt polskiego filmoznawstwa określenia niemieckiego badacza Josefa Kloppenburga. K. Kozłowski, Stanely Kubrick, Warszawa 2013, s. 180.

[27] G. Hacquard, La musique et le cinéma, Paris 1959, s. 4. Podaję za: P. Pomostowski, op.cit., s. 28. [28] Sformułowań „muzyka diegetyczna” oraz "niediegetyczna” konsekwentnie używają w swoich szkicach, między innymi, Alyssa Aska (Introduction to the Study of Video Game Music), Karen Collins (Playing with Sound: A Theory of Interacting with Sound and Music in Video Games) oraz Neil Lerner (Mario's Dynamic Leaps: Musical Innovations (and the Specter of Early Cinema) in Donkey Kong and Super Mario Bros.).

[29] K. Jørgensen, Left in the dark: playing computer games with the sound turned off, [w:] From Pac-Man to Pop Music..., s. 164. jest najużyteczniejsza, gdyż zakładam, że, w zależności od kontekstu badawczego, każda z nich może okazać się analitycznie funkcjonalna. Decyzja o wykorzystaniu określeń „dźwięki diegetyczne” oraz „niediegetyczne” motywowana jest tym, że są to sformułowania, które najczęściej stosują ludomuzykolodzy[28] (wskazując zresztą na ich filmoznawczą proweniencję). Uznaję je ponadto za poręczne interpretacyjnie i semantycznie, gdyż w niniejszym artykule stosuję określenie „diegetyczny”, opisując nie tylko audiosferę, ale również poszczególne aspekty świata przedstawionego (diegetycznego).

Podstawową funkcją dźwięków diegetycznych zarówno w kinematografii, jak i w grach wideo jest budowanie wiarygodności świata przedstawionego[29]. Starannie zaprojektowana diegetyczna warstwa audialna służy designerom do przekazywania informacji o obiektach, wydarzeniach oraz lokacjach, a zatem istotnie wpływa na rozwój narracji i zakres jej możliwych interpretacji. Dla przykładu użytkownik w grze Red Dead Redemption II (Rockstar Games, 2018), wędrując po obozie bandytów, do których należy kierowany przez niego awatar, może podsłuchać rozmowy członków gangu lub dołączyć do aktywności, w których biorą oni udział (na przykład posłuchać granego na gitarze utworu i zatańczyć do melodii). Dialogi, odgłosy oraz muzyka przynależą do świata przestawionego, a ich nadrzędnym celem staje się dostarczanie informacji o współtowarzyszach i przekonanie gracza do zaangażowania się w obozowe życie. Konstrukcja ścieżki dźwiękowej, polegająca na łączeniu różnorodnych dźwięków (dialogów, muzyki oraz odgłosów, jak w obozie w Red Dead Redemption II), jak również ich odpowiednia głośność oraz natężenie (w God of War te właściwości dźwięku zmieniają się w zależności od odległości protagonisty od warsztatu - im bliżej Kratos znajduje się Broka i Sindriego, tym głośniejsze stają się odgłosy) tworzą złożoną, wielowarstwową audiosferę, za pomocą której designerzy kształtują koherencję świata przedstawionego.

Dźwięki niediegetyczne z kolei służą między innymi audialnej ilustracji przestrzeni i zdarzeń 
rozwijających się w ich obrębie[30]. Użytkownik Red Dead Redemption II w toku rozgrywki dowolnie nawiguje w różnorodnych lokacjach symulujących Stany Zjednoczone przełomu XVIII i XIX wieku. Może opuścić lesiste środkowe stany i udać się w kierunku bagnistych południowych regionów. Wraz z dywersyfikacją przestrzeni konsekwentnie zmienia się również ścieżka dźwiękowa. W audiosferze pojawiają się momenty muzyczne wygrywane na banjo instrumencie muzycznym charakterystycznym dla południowych stanów. Funkcją wykorzystania muzyki etnicznej, która ma charakter adaptatywny, gdyż włącza się w określonym miejscu świata diegetycznego, jest audialna charakterystyka nowego obszaru, wpływająca na to, co potocznie określane jest atmosferą bądź klimatem sceny. Użycie dźwięków niediegetycznych służy zatem stymulowaniu emocji graczy. W grze wideo Wiedźmin 3: Dziki Gon (CD Projekt RED, 2015) pojawienie się muzyki i szeptów niediegetycznych na bagnach wskazuje na niebezpieczeństwo, które niesie ze sobą przebywanie w tym obszarze, podczas gdy śpiewana a cappella piosenka Twinkle, Twinkle w digitalnym horrorze Dead Space (Electronic Arts, 2008) buduje efekt grozy.

Powyższe funkcje diegetycznej i niediegetycznej ścieżki dźwiękowej są, jak zostało wspomniane, właściwe również kinematografii. Istotną różnicą $\mathrm{w}$ odniesieniu do filmu jest to, że wykorzystanie obu rodzajów audiosfery służy w grach wideo nadrzędnemu celowi, którym jest aktywizowanie interakcji użytkownika. Scena walki w God of War może rozpocząć się odwrotnie niż zostało to opisane we wprowadzeniu do niniejszego artykułu. Prawdopodobna jest sytuacja, że to Kratos dostrzeże wrogów, zanim oni go zauważą. W takim przypadku system gry nie wygeneruje ani charakterystycznej, orkiestrowej muzyki niediegetycznej, ani diegetycznych odgłosów, które zazwyczaj towarzyszą walce (wyjmowanie broni w przypadku ciężko opancerzonych wrogów; głośne śmiechy podczas starcia $\mathrm{z}$ wiedźmami; świst skrzydeł zapowiadający atak latających stworzeń itd.). Nieobecność powyższych dźwięków odzwierciedla status awatara w rzeczywistości diegetycznej. Ścieżka audialna sygnalizuje, że bohater nie jest w tym momencie zagrożony, a w konsekwencji wpływa na sposób prowadzenia rozgrywki - użytkownik może przygotować się do walki, zmieniając broń, opancerzenie czy też przemyśleć dotychczasową taktykę oraz zaskoczyć przeciwników. Dopiero wtedy, gdy antagoniści dostrzegą Kratosa, pojawia się ścieżka dźwiękowa, która rytmizuje scenę walki. Wykorzystanie dźwięków - zarówno diegetycznych, jak i niediegetycznych - stymuluje zatem proces nawigowania gracza $\mathrm{w}$ przestrzeni oraz wpływa na interakcję ze znajdującymi się w niej obiektami i postaciami[31].

W tym kontekście interesujące wydaje się pytanie, które aspekty audiosfery - te posiadające swoją proweniencję $\mathrm{w}$ świecie diegetycznym, czy te, których źródła należy poszukiwać poza rzeczywistością przedstawioną - są istotniejsze dla poczucia zanurzenia użytkownika w rozgrywkę i zaangażowania w narrację gry. Alyssa Aska, rozstrzygając powyższy problem badawczy, wskazuje, że „w immersyjnych, a więc realistycznych grach większą rolę pełni starannie zaprojektowana diegetyczna ścieżka dźwiękowa; dźwięki diegetyczne są znacznie głośniejsze i wyraźniejsze niż muzyka niediegetyczna" [32]. Badaczka twierdzi, że dźwięki niediegetyczne (zwłaszcza muzyka) charakterystyczne są dla gier nierealistycznych (a zatem mniej immersyjnych), takich jak cyfrowe puzzle, gry turowe oraz arkadowe. Aska dowodzi, że dźwięki diegetyczne budują wiarygodność świata przedstawionego, nadając warstwie obrazowej głębię, podczas gdy niediegetyczne pełnią funkcję podrzędną względem obrazu i w znacznie mniejszym stopniu wpływają na zaangażowanie użytkownika $\mathrm{w}$ świat przedstawiony. Sądzę, że powyższa konstatacja jest znaczącym uproszczeniem, biorąc pod uwagę,

[30] K. Collins, Playing with Sound..., s. 131.

[31] K. Jørgensen, Left in the dark: playing computer games with the sound turned off, [w:] From Pac-Man to Pop Music..., s. 164.

[32] A. Aska, op.cit., s. 105. 
że dźwięki niediegetyczne - tak w grach wideo, jak i filmach - konotują określone znaczenia (muzyka towarzysząca zmianie lokacji w Red Dead Redemption II), przekazują informacje dotyczące działań podejmowanych przez uczestników sceny (ścieżka dźwiękowa ilustrująca atak wrogów w God of War) oraz wpływają na jej emocjonalny odbiór (chromatyczny dźwięk generowany podczas śmierci bohatera w Donkey Kong).

Karen Collins uzupełnia rozpoznania Aski o konteksty związane z gameplayem, wskazując, że diegetyczna warstwa audialna angażuje użytkownika w grę znacznie bardziej niż dźwięki niediegetyczne, gdyż zazwyczaj otwarta jest na rekonfigurację, tj. podlega modyfikacjom ze strony gracza [33]. Badaczka, aby zilustrować tę tezę, przywołuje przykład zaczerpnięty z Grand Theft Auto: San Andreas (Rockstar Games, 2004), w którym użytkownik może zmieniać stacje radiowe podczas jazdy samochodem. Istotnym elementem gry są pościgi samochodowe, dlatego umożliwienie graczowi wyboru muzyki towarzyszącej scenie pozwala nadać jej określony (w domyśle: niepowtarzalny) rytm i dynamikę. Gracz otrzymuje zatem możliwość rekonfigurowania diegetycznej audiosfery i w ten sposób indywidualizuje swoją rozgrywkę, co wpływa na jego zanurzenie w wirtualną rzeczywistość. Innymi słowy, dźwięki diegetyczne, które są reaktywne, a więc kształtowane przez konkretne wybory użytkownika, istotnie wpływają na immersję gracza.

Najistotniejszą różnicą w sposobie funkcjonowania warstwy audialnej gier wideo w porównaniu z dźwiękiem w filmie jest to, że ulega ona nieustannym przetworzeniom. Dźwięki reaktywne, pojawiające się bezpośrednio w następstwie podejmowanych przez gracza działań, indywidualizują audiosferę, której rytm i dynamika zależy od jego interakcji z systemem. Natomiast dźwięki antycypujące (zazwyczaj o charakterze adaptatywnym) budują oczekiwania względem tego, co wydarzy się w świecie diegetycznym i są konsekwencją decyzji, które

[33] K. Collins, Playing with Sound..., s. 131. użytkownik podjął podczas rozgrywki. Za pośrednictwem dźwięków reaktywnych i antycypujących dochodzi więc do sprzężenia zwrotnego w komunikacji gracza z oprogramowaniem. Kiedy użytkownik wydaje polecenia systemowi, otrzymuje audialną wiadomość zwrotną, dzięki czemu orientuje się, że powzięte przez niego działanie zostało zrealizowane albo w określony sposób wpłynęło na świat diegetyczny. Audiosfera gier wideo - podobnie jak aspekty wizualne, na przykład inscenizacja - okazuje się otwarta na konfigurację, modyfikowalna i wariacyjna, a zatem, jak sądzę, jest kluczowa dla zrozumienia złożonego zagadnienia interaktywnej narracyjności gier wideo.

Konsekwencją rozwoju ludomuzykologii w Stanach Zjednoczonych, łączącej badania nad grami wideo $\mathrm{z}$ teoriami muzyki i filmu, stało się stworzenie funkcjonalnej bazy pojęciowej oraz wypracowanie metod badawczych umożliwiających wieloaspektową analizę warstwy audialnej tekstów interaktywnych. Na gruncie polskiej myśli groznawczej wciąż jednak brakuje kompleksowych opracowań dotyczących dźwięków w grach. Wydaje się, że w przyszłych badaniach nad grami warto uzupełnić tę lukę, gdyż - jak zostało wskazane - rekonfigurowalna ścieżka audialna istotnie wpływa na doświadczanie wirtualnych rzeczywistości przez użytkowników, stymuluje immersję, tj. proces zanurzania się w grę i poczucia niezmediatyzowanego uczestnictwa $\mathrm{w}$ świecie przedstawionym oraz determinuje rozwój digitalnych narracji.

\section{B I B L I O G R A F I A}

Aska A., Introduction to the Study of Video Game Music, Ebook: Lulu.com 2017

Bordwell D., Thompson K., Film Art. Sztuka filmowa, przeł. B. Rosińska, Warszawa 2014

Chion M., Audio-wizja. Dźwięk i obraz w kinie, przeł. K. Szydłowski, Warszawa, Kraków 2012

Chion M., La voix du cinéma, Paris 1982

Collins K., Game Sound: An introduction to the history, theory, and practice of video game music and sound design, Cambridge 2008

Collins K., Playing with Sound: A theory of interacting with sound and music in video games, Cambridge 2013 
Cook N., Pettengill R. (red.), Taking It to the Bridge: Music as performance, Michigan 2013

Glasser M., Dialog in film and fiction, [w]: Explorations in National Cinemas. The 1977 Film Studies Annual: Part One, red. B. Lawtion, J. Staiger, New York 1977 Hacquard G., La musique et le cinéma. Paris 1959

Iuppa N., Borst T., Story and Simulations for Serious Games: Tales from the trenches, Burlington, Oxford 2007

Jørgensen K., Left in the dark: playing computer games with the sound turned off, [w:] From Pac-Man to Pop Music: Interactive audio in games and new media, red. K. Collins, Surrey 2008, s. 163-176

Kaae J., Theoretical approaches to composing dynamic music for video games, [w:] From Pac-Man to Pop Music: Interactive Audio in Games and New Media, red. K. Collins, Surrey 2008, s. 75-92

Kozłowski K., Stanley Kubrick, Warszawa 2013

Lerner N., Mario's dynamic leaps: musical innovations (and the specter of early cinema) in Donkey Kong and Super Mario Bros., [w:] Music in Video Games: Studying Play, red. K.J. Donelly, W. Gibbons N. Lerner, New York 2014, s. 3-23.

Manovich L., Język nowych mediów, przeł. P. Cypryański, Warszawa 2006

Moseley R., Playing games with music (and vice versa): ludomusicological perspectives on Guitar Hero and Rock Band, [w:] Taking It to the Bridge: Music as performance, red. N. Cook, R. Pettengill, Michigan 2013, s. 279-318

Pająk J., Dźwięk w filmie. Między sztuką a rzemiosłem, Warszawa 2018

Phillips W., A Composer's Guide to Game Music, Cambridge 2014
Pomostowski P., Reżyser na ścieżce dźwiękowej. Funkcje muzyki w twórczości filmowej Romana Polańskiego, Poznań 2018

Richard T., Summers D., Video Game Music: History, form and genre, Bristol 2012

Slowik M., After the Silents: Hollywood film music in the early sound era, 1926-1934, New York 2014

Summers T., Understanding Video Game Music, Cambridge 2016

Sweet M., Writing Interactive Music for Video Games: A composer's guide, New Jersey 2015

Whalen Z., Play along - an approach to videogame music, "Game Studies: The International Journal of Computer Game Research" 2004, nr 4(1), <http://www.gamestudies.org/0401/whalen/>, dostęp: 15.12.2019

\section{Y TOWANE GRY WIDEO}

Brothers: A Tale of Two Sons [gra wieloplatformowa], Starbreeze Studios, 2013

Dead Space [gra wieloplatformowa], EA Redwood Shores, 2008

Donkey Kong [gra wieloplatformowa], Nintendo, 1981

God of War [PS4], SIE Santa Monica Studio, 2018

Grand Theft Auto: San Andreas [gra wieloplatformowa], Rockstar North, 2004

Limbo [gra wieloplatformowa], Playdead, Double Eleven, 2010

Red Dead Redemption II [gra wieloplatformowa], Rockstar Games, 2018

Super Mario Bros. [NES], Nintendo, 1985

Wiedźmin 3: Dziki Gon [gra wieloplatformowa], CD Projekt RED, 2015 